\title{
Obama and the opportunity to eliminate nuclear weapons
}

A s US President Barack Obama assumes office on this historic day, we would like to remind him of his recent statement that "A world without nuclear weapons is profoundly in America's interest and the world's interest. It is our responsibility to make the commitment, and to do the hard work to make this vision a reality."

The Cold War is over, but the threat of nuclear war is not. Little progress has been made since 1989 when the Berlin Wall collapsed. In fact, the threat of nuclear annihilation has escalated. In 1972, when 5 nuclear nations (France, Britain, China, Russia and the United States) signed the Non-Proliferation Treaty, they agreed to rapidly disarm. They have done the opposite. Although President George H.W. Bush unilaterally eliminated some tactical weapons from Europe, President Bill Clinton failed to initiate the negotiation for full elimination of the superpower nuclear arsenals. Now Israel, India and Pakistan, which are not parties to the treaty, all have weapons, and other countries are keen to develop them using enriched uranium or plutonium from their nuclear power reactors.

Approximately 25 000-30 000 nuclear weapons exist in the world. The United States and Russia own $97 \%$ of them. ${ }^{2}$ Together, the US and Russia currently maintain 2581-4309 $\mathrm{H}$-bombs on alert and neither has repudiated a policy of launch on warning. The Russians are suitably paranoid about this situation, especially because their early warning systems are seriously degraded and early detection of a US attack would be limited.

India has about 65 nuclear weapons and Pakistan up to $50 .^{2}$ Support within Pakistan for the Taliban raises credible fears that extremists could obtain access to Pakistani nuclear material, particularly during this time of recent political instability. A smaller nuclear conflict between Pakistan and India could instigate a full-scale nuclear exchange involving other nations during the total confusion and international anxiety that such a situation would provoke. For example, on 9/11, the anxiety was such that the US nuclear alert codes were raised from DEFense readiness CONdition (DEFCON) 5 to DEFCON 3, the second highest state of alert before the launch code is operable.

Nuclear war can be initiated by accident, computer or human error, or by design - whether by a country, terrorist or rogue nation. Many close calls have been recorded. ${ }^{3}$ However, because the Cold War is over, leading politicians do not discuss this situation. Hence, people have settled into a comfortable state of either psychic numbing or ignorance.

This is the ultimate public health issue. Once launched, nuclear weapons would take 12-30 minutes to reach their targets, during which time the commander-in-chief of the "at- tacked" country would have a decision time of 3 minutes to retaliate. The event would be over in 1 hour. ${ }^{4}$ The current nuclear arsenal remains more than sufficient to produce a nuclear winter and end most life on earth. Even a nuclear war between India and Pakistan, using less than $0.3 \%$ of the current nuclear arsenal, could produce climate change unprecedented in recorded human history. ${ }^{5}$ Moreover, nuclear weapons have cost US taxpayers more than $\$ 5.8$ trillion dollars. ${ }^{6}$ This massive fortune could have been used instead to eliminate global hunger and preventable diseases.

Physicians are credible, powerful leaders in society. We led the movement in the 1980s against nuclear weapons by educating about the medical consequences of nuclear war. Other professional organizations emulated us and within 5 years, $80 \%$ of Americans, previously unaware of the danger, were opposed to nuclear war. Again we must mobilize our colleagues to lead a massive global movement for nuclear abolition - the ultimate form of preventive medicine. President Obama's words signal a critical new opportunity. He requires our help in this noble commitment.

\section{Helen Caldicott MD}

Pediatrician

Founding President, Physicians for Social Responsibility

Bermagui, Australia

With the Editorial-Writing Team (Paul C. Hébert MD MHSc, Matthew B. Stanbrook MD PhD, Barbara Sibbald BJ, Ken Flegel MDCM MSc, Noni MacDonald MD MSc and Amir Attaran LLB DPhil)

Competing interests: See www.cmaj.ca/misc/edboard.shtml for the EditorialWriting Team's statements. None declared for Helen Caldicott.

Dr. Caldicott is the author of the book If you love this planet.

\section{REFERENCES}

1. Obama B. Statement on call for world without nuclear weapons. Obama-Biden; 2008. Available: www.barackobama.com/2008/01/17/statement_on_call_for _world_wi.php (accessed 2008 Dec. 11).

2. Norris RS, Kristensen HM. Global nuclear stockpiles, 1945-2006. Bull At Sci 2006; 62:64-6.

3. Forrow L, Blair BG, Helfand I, et al. Accidental nuclear war - a post-cold war assessment. N Engl J Med 1998;338:1326-31.

4. Caldicott H. Nuclear power is not the answer. New York (NY): The New Press, 2006

5. Robock A, Toon B. Climatic effects of nuclear conflict. Department of Environmental Sciences, Rutgers University, New Brunswick (NJ) and Department of Atmospheric and Oceanic Sciences, University of Colorado, Boulder (CO). Available: http://climate.envsci.rutgers.edu/nuclear/RobockToonSummary.pdf

6. Pincus W. US has spent $\$ 5.8$ trillion on nuclear arms since 1940 , study says Washington Post 1998 July 1; Sect A:2. 